\title{
Three new species of Helicopsyche (Trichoptera, Helicopsychidae) from northern Vietnam, with a key to Helicopsyche species of Vietnam
}

Johanson K.A. \& Pham H.-T. 2011. Three new species of Helicopsyche (Trichoptera, Helicopsychidae) from northern Vietnam, with a key to Helicopsyche species of Vietnam. European Journal of Taxonomy 6: 1-10. http:// dx.doi.org/10.5852/ejt.2012.6

\section{Kjell A. JOHANSON ${ }^{1}$ \& Hong-Thai PHAM ${ }^{2}$}

${ }^{1}$ Swedish Museum of Natural History, Entomology Department, Box 50007, SE-104 05 Stockholm. E-mail: kjell.arne.johanson@nrm.se (corresponding author)

${ }^{2}$ Department of Insect Systematics, Institute of Ecology and Biological Resources, 18 Hoang Quoc Viet, Cau Giay, Ha Noi, Vietnam. E-mail: phamthai1976@yahoo.com

\begin{abstract}
Three new species of Helicopsyche Siebold, 1856 are described from Vietnam: Helicopsyche melina sp. nov., Helicopsyche meander sp. nov., and Helicopsyche lamnata sp. nov. All species were described from Melinh Station for Biodiversity in the Me Linh District of Vinh Phuc Province. The species were collected mainly in Malaise traps situated across a small stream surrounded by lowland forest. Some individuals were also collected on light in traps situated at the stream bank.
\end{abstract}

Key words. Vietnam, Helicopsychidae, taxonomy, Vinh Phuc, stream.

\section{Introduction}

With 270 described species the snail-case caddisfly genus Helicopsyche Siebold, 1856, ranks as the tenth largest genus in the order Trichoptera. The genus has been recorded from all major faunal regions, except Antarctica (Johanson 1998) and has the highest species diversity southern latitude interval $5-30^{\circ}$ and southern latitude interval $15-45^{\circ}$ (Johanson 1997). With 30 described Helicopsyche species (Johanson 1999), the 17,000 $\mathrm{km}^{2}$ large New Caledonian Grande Terre has the highest density of species in the world. The larva of all species are reported to build dextrally coiled larval cases made from sand grains and glued together by silk. They live in permanent and preferably running water bodies, often in well-shaded forest streams and rivers. The 71 previously described Helicopsyche species of the Oriental Region (Morse 2011) are classified in two subgenera, Galeopsyche Johanson, 1998 and Helicopsyche Siebold, 1856 (Johanson 1998). The first record of Helicopsyche from Vietnam was that of Helicopsyche azwudschgal Malicky, 1995, described from Tam Dao National Park at 800-1,100 m altitude. Schefter \& Johanson (2001) described three more species from the country: Helicopsyche khemoiensis Schefter \& Johanson, 2001 (from Nghe An District), Helicopsyche azunensis Schefter \& Johanson, 2001, and Helicopsyche dacklestensis Schefter \& Johanson, 2001 (the two latter from Gia Lai District). Malicky (2010) listed the following two additional species from Vietnam: Helicopsyche boniata Malicky \& Chantaramongkol, 1992, Helicopsyche admata Malicky \& Chantaramongkol, 1992, both originally described from Thailand. With the addition of the three new species recorded and described below, the 
known diversity of Helicopsyche in Vietnam is nine species, only slightly lower than found in Thailand (fourteen spp.).

This research was executed to increase our knowledge about the taxonomic species diversity and morphological variation in the family Helicopsychidae, as well as to increase our understanding of the biogeography of individual species in the group.

\section{Material and methods}

The material was collected in light traps between 4- $5^{\text {th }}$ April and Malaise traps between 4-12 $2^{\text {th }}$ April 2011 in the Vinh Phuc Province, Me Linh District, at a stream near Ngoc Thanh Village, Melinh Station for Biodiversity. It comprises 357 male and 81 female Helicopsyche; the males divided into three species while the females are not associated or determined.

The specimens were identified to morphospecies without initial treatment of the genitalia. Before illustrated the abdomen of the species were macerated in ProteinaseK for extraction of DNA, and for a short period in hot $8 \% \mathrm{KOH}$ to remove remaining tissue. Each abdomen was temporarily mounted in Euparal on a microscope slide and illustrated using a drawing tube mounted on a Leitz Ortholux II light microscope. The individual illustrations were scanned in 600 dpi gray scale and used as a digital background layer in Adobe ${ }^{\circledR}$ Photoshop ${ }^{\circledR}$ CS v.8.0. The final illustration was drawn using a Wacom ${ }^{\circledR}$ sketchpad and digital pen. After illustration, upper layer was saved into final illustrations. The abdomen with genitalia was thereafter transferred into $80 \%$ ethanol in a micro-vial, together with the rest of the specimen. Terminology for morphological characters mainly follows that of Johanson (1998) and Oláh \& Johanson (2008).

The material is deposited in the following institutions:

IEBR $=$ Institute of Ecology and Biological Resources, Hanoi, Vietnam

NHRS $=\quad$ Swedish Museum of Natural History, Stockholm, Sweden

\section{Results}

\section{Helicopsyche melina sp. nov.}

Fig 1

\section{Diagnosis}

Helicopsyche melina sp. nov. is most similar to H. admata Malicky \& Chantaramongkol, 1992, H. dacklestenensis Schefter \& Johanson, 2001 and H. nastia Malicky \& Melnitsky (Melnitsky \& Malicky 2008) particularly due to the presence of four-segmented maxillary palps in combination with the nearly similar shape of the gonopods and tergum $\mathrm{X}$ in lateral view. The new species is easily distinguished from these by the presence of a well-developed transverse plate of segment IX located at mid-height of posterior part of the segment; the primary branch of each gonopod is produced anterad; and the secondary branch of each gonopod is long, straight, and oriented in right angle to the primary branch of the gonopods.

\section{Etymology}

Melina, named after the Melinh Station for Biodiversity, near the type locality. 


\section{Material examined}

\section{Holotype $\widehat{\sigma}$}

VIETNAM: Vinh Phuc Prov, Me Linh District, stream near Ngoc Thanh Village, Melinh Station for

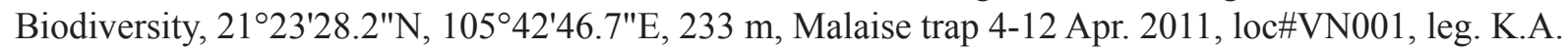
Johanson, P.H. Thai \& T.T. Du (NHRS, alcohol) [DNA voucher IP7].
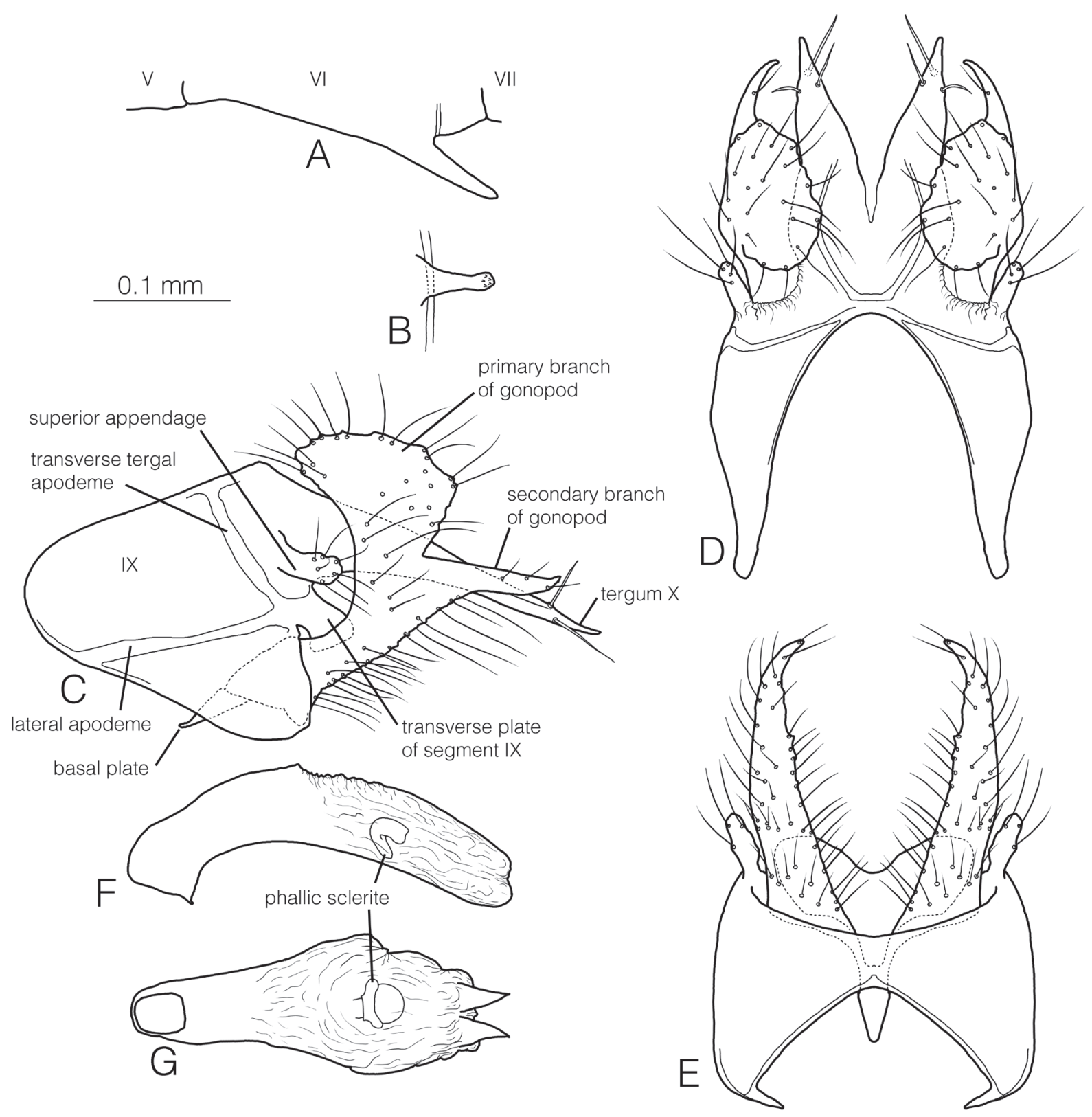

Fig. 1. Helicopsyche melina sp. nov., ठ holotype. A. abdominal sternum VI, lateral view. B. abdominal sternal process VI, ventral view. C. genitalia, lateral view. D. genitalia, dorsal view. E. genitalia, ventral view. F. phallus, lateral view. G. phallus, ventral view. 
Paratypes $\hat{O}$

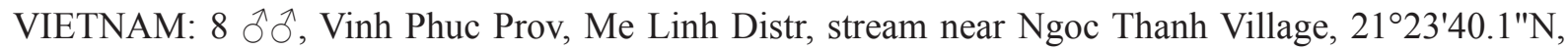
$105^{\circ} 42^{\prime} 54.9^{\prime \prime E}$, light trap 5 Apr. 2011, loc\#VN008, leg. K.A. Johanson, P.H. Thai \& T.T. Du (IEBR,

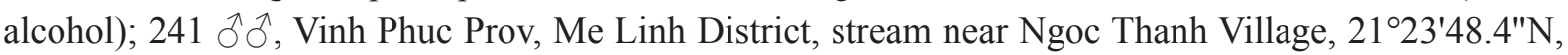
105²'56.1"E, 186 m, Malaise trap 5-12 Apr. 2011, loc\#VN006, leg. K.A. Johanson, P.H. Thai \& T.T. Du (NHRS, alcohol); 20 ऽึ, Vinh Phuc Prov, Me Linh District, stream near Ngoc Thanh Village, 21 ${ }^{\circ} 23^{\prime} 48.4^{\prime \prime N}, 105^{\circ} 42^{\prime} 56.1^{\prime \prime E}, 186$ m, Malaise trap 5-12 Apr. 2011, loc\#VN006, leg. K.A. Johanson, P.H. Thai \& T.T. Du (IEBR, alcohol); 34 $\lesssim \widehat{\jmath}$, Vinh Phuc Prov, Me Linh Distr, stream near Ngoc Thanh

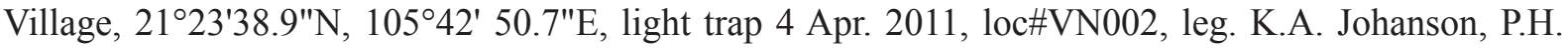
Thai \& T.T. Du (NHRS, alcohol); $2 \hat{\jmath} \widehat{\partial}$, Vinh Phuc Prov, Me Linh Distr, stream near Ngoc Thanh Village, $21^{\circ} 23^{\prime} 58.7^{\prime \prime} \mathrm{N}, 105^{\circ} 42^{\prime} 49.8^{\prime \prime E}$, light trap 5 Apr. 2011, loc\#VN007, leg. K.A. Johanson, P.H. Thai \& T.T. Du (NHRS, alcohol).

\section{Description}

MaXILLARY PALPS. Four-segmented, each segment gradually shorter distally. Pair of interantennal setal warts bean shaped, each about as long as width of individual scapus. Each scapus about as long as each basal segment of maxillary palps. Spur formula 1,2,4; each foreleg spur slightly shorter than each first tarsomere.

LENGTH. Forewing 2.8-3.6 mm, hind wing 2.3-2.9 mm ( $\mathrm{N}=10)$.

Male ABdomen And Genitalia. (Fig. 1) Sternal process VI about one-fifth as long as sternum VI, straight, oriented posteroventrad; slightly tapering in lateral view (Fig. 1A); with slightly club-shaped apex in ventral view (Fig. 1B). Segment IX about as long as high in lateral view (Fig. 1C); each anterior lobe of segment IX (Fig. 1C) narrowly and symmetrically ellipsoid in lateral view, oriented anterad; anterodorsal and anteroventral margins almost straight (Fig. 1C); in dorsal view, inner margin forming narrowly ellipsoid cavity (Fig. 1D); in ventral view, without central posterior process (Fig. 1E); inner margin forming nearly triangular cavity; lateral apodemes nearly horizontal (Fig. 1C), widening anteriorly, meeting anterior margin, sub-marginal line absent; tergal transverse apodemes well-developed; sternal transverse apodeme absent. Transverse plate of segment IX located at mid-height of posterior margin of segment IX; in lateral view almost club-shaped, curving ventrad (Fig. 1C); in ventral view forming broadly heart-shaped plate above basal part of gonopods (Fig. 1E). Tergum X, in lateral view, oriented posterad (Fig. 1C), almost straight, tapering along its length; apex strongly pointed (Fig. 1D); in dorsal view (Fig. 1D), deeply divided into pair of tapering, divergent branches, with about 3 pairs of equally long megasetae in apical group, starting opposite to apex of gonopods in lateral view (Fig. 1C). Superior appendages tubular (Fig. 1D), slightly curving dorsally. Primary branch of gonopods, in lateral view (Fig. 1C), oriented dorsally, broadened distad to mid-height; anterior margin smooth, strongly concave; dorsal and posterior margins edged, undulating, posteroventral margin almost straight (Fig. 1C); apices produced mesad into rounded lobes above basolateral part of tergum X. Secondary branch of gonopods nearly as long as secondary branch of gonopods; slender, almost straight in lateral view, except apex slightly curving dorsad; with few setae; curving mediad in ventral view (Fig. 1E). Basomesal lobes absent. Basal plate, in lateral view (Fig. 1C), nearly straight, narrowing along its length, slightly produced beyond anteroventral margin of segment IX in lateral view (Fig. 1C); narrow in ventral view (Fig. 1E). Phallic apparatus, lateral view, tube-shaped along its length (Fig. 1F), narrowest shortly after basis, apex about as broad as base; nearly straight after mid-length; in ventral view, with basis narrow (Fig. 1G); widest immediately after mid-length; endotheca weakly produced, posteroventral part not sclerotized, except pair of weakly sclerotized pair of triangular processes distally of phallic sclerite. 


\section{Helicopsyche meander sp. nov.}

Fig. 2

\section{Diagnosis}

Helicopsyche meander sp. nov. is most similar to H. lamnata sp. nov., H. anaktangga Malicky, 1995, $H$. anaksaku Malicky, 1995, H. minyas Malicky \& Nawvong (Malicky et al. 2004) and H. cymodoce Schmid, 1993, particularly due to the presence of two-segmented maxillary palps in combination with the nearly similar shape of the gonopods in lateral view. The new species is distinguished from $H$. anaktangga, $H$. anaksaku, $H$. minyas and $H$. cymodoce by the pointed apex of tergum $\mathrm{X}$ in lateral view; and from $H$. lamnata sp. nov., H. anaksaku and H. minyas by the more strongly S-shaped gonopods. It is furthermore separated from H. lamnata sp. nov. by the absence of a central posterior process of segment IX.

\section{Etymology}

Meander, named after the shape of the gonopods, resembling a meandering river.

\section{Material examined}

Holotype $\widehat{O}$

VIETNAM: Vinh Phuc Prov, Me Linh District, stream near Ngoc Thanh Village, Melinh Station for

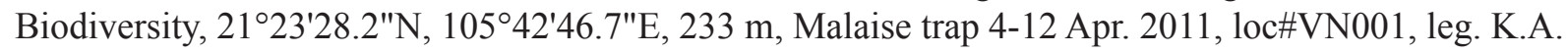
Johanson, P.H. Thai \& T.T. Du (NHRS, alcohol) [DNA voucher IP7].

\section{Description}

MaXillary PalPs. Two-segmented, with distal segment slightly longer than basal segment. Pair of interantennal setal warts semi-spherical, elevated. Each scapus about as long as each basal segment of maxillary palps. Spur formula 1,2,4; each foreleg spur slightly shorter than each first tarsomere.

LENTH. Forewing $3.7 \mathrm{~mm}$, hind wing $2.8 \mathrm{~mm}(\mathrm{~N}=1)$.

Male abdomen and genitalia. (Fig. 2) Sternal process VI about one-eighth as long as sternum VI, straight, oriented posteroventrad; slightly tapering in lateral view (Fig. 2A); pointed in ventral view (Fig. 2B). Segment IX about $1.5 \mathrm{x}$ taller than long in lateral view (Fig. 2C); each anterior lobe of segment IX (Fig. 2C) irregularly narrowing anteriorly in lateral view, asymmetrical, oriented anterad; anterodorsal margin almost straight; anteroventral margin concave (Fig. 2C); in dorsal view, inner margin forming narrowly ellipsoid cavity (Fig. 2D); in ventral view, without central posterior process (Fig. 2E); inner margin forming wide, almost rectangular cavity; lateral apodemes nearly horizontal (Fig. 2C), each parallel-sided along their length, meeting anterior margin; sub-marginal line present above lateral apodemes; tergal transverse apodemes present, fading immediately above superior appendages; sternal transverse apodeme present along posterior margin of segment IX (Fig. 2C). Transverse plate absent. Tergum X, in lateral view, oriented posteroventrad (Fig. 2C), slightly sigmoid, tapering towards mid-length, apex strongly club-shaped, slightly curving dorsally (Fig. 2C); in dorsal view (Fig. 2D), deeply and widely divided into pair of parallel-sided and parallel-running branches, with 3 pairs of equally long megasetae in apical group, starting well before apex of gonopods in lateral view (Fig. 2C). Superior appendages club-shaped (Fig. 2C), oriented ventrad. Primary branch of gonopods, in lateral view (Fig. 2C), with basal part oriented posterad before strongly bending dorsad, angling posterad at half-length, apical part produced mesad above tergum X; almost parallel-sided along their length; anterior margin smooth, strongly concave; dorsal and posterior margins undulating. Secondary branch of gonopods absent. Basomesal lobes long, tuboid, each with pair of apical setae; sigmoid in lateral view (Fig. 2D), parallel-sided with diverging apex in ventral view (Fig. 2E). Basal plate, in lateral view (Fig. 2C), curving anteroventrad, narrowing along its length from posterior to anterior 
end, slightly produced beyond anteroventral margin of segment IX in lateral view (Fig. 2C); widely triangular in ventral view (Fig. 2E). Phallic apparatus, lateral view, irregularly tube-shaped along its length (Fig. 2F), apex about as broad as base; nearly straight after mid-length; in ventral view, with basis narrow (Fig. 2G); widest after mid-length; endotheca weakly produced, posteroventral part not sclerotized, except single, weakly sclerotized triangular processes distally of phallic sclerite.
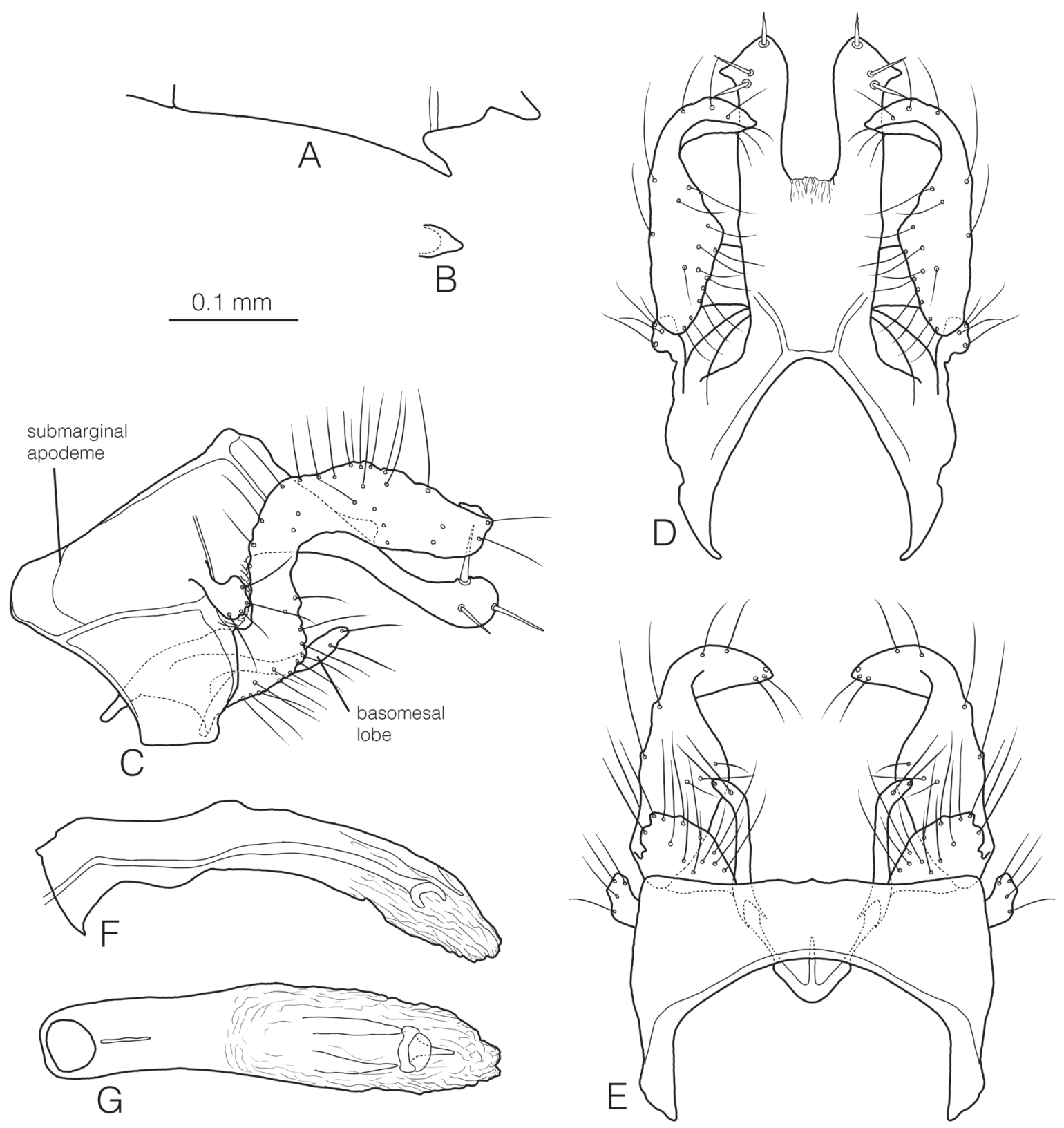

Fig. 2. Helicopsyche meander sp. nov., $\overbrace{}^{\Uparrow}$ holotype. A. abdominal sternum VI, lateral view. B. abdominal sternal process VI, ventral view. C. genitalia, lateral view. D. genitalia, dorsal view. E. genitalia, ventral view. F. phallus, lateral view. G. phallus, ventral view. 
Helicopsyche lamnata sp. nov.

Fig. 3

\section{Diagnosis}

Helicopsyche lamnata sp. nov. is most similar to H. vongsombathi Johanson \& Malm, 2007, from which it is easily distinguished by the presence of a central posterior process of segment IX and the distal part of the gonopods are more strongly produced posteriorly. The species also resembles $H$. meander sp. nov., particularly by the nearly club-shaped apex of tergum X in lateral view, but in H. lamnata sp. nov. the $\mathrm{VI}^{\text {th }}$ sternal process is much longer and the gonopods are less sharply sigmoid.

\section{Etymology}

Lamnata, plate-like in Latin, refers to the process on the posterior margin of sternite IX.

\section{Material examined}

Holotype $\hat{\sigma}$

VIETNAM: Vinh Phuc Prov, Me Linh District, stream near Ngoc Thanh Village, Melinh Station for

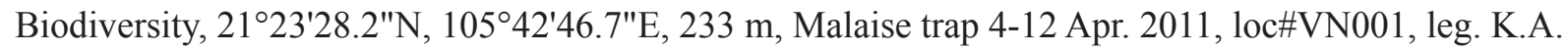
Johanson, P.H. Thai \& T.T. Du (NHRS, alcohol) [DNA voucher IP9].

\section{Paratype}

Same data as holotype, except (IEBR, alcohol).

\section{Description}

MaXiLlary PalPs. Two-segmented, all segments sub-equal in length. Pair of interantennal setal warts very large, spherical, elevated, densely covered by long setae. Each scapus slightly longer than individual segments of maxillary palps. Spur formula 1,2,4; each foreleg spur nearly as long as each first tarsomere.

Length. Forewing $4.0 \mathrm{~mm}$, hind wing $3.1 \mathrm{~mm}(\mathrm{~N}=1)$.

Male abdomen and genitalia. (Fig. 3) Sternal process VI about two-fifths as long as sternum VI, straight, oriented posteroventrad; parallel-sided in lateral view (Fig. 3A); almost parallel-sided in ventral view (Fig. 3B). Segment IX slightly taller than long in lateral view (Fig. 3C); each anterior lobe of segment IX (Fig. 3C) smoothly narrowing anteriorly in lateral view, asymmetrical, oriented anterodorsad; anterodorsal margin almost straight; anteroventral margin concave (Fig. 3C); in dorsal view, inner margin forming narrowly ellipsoid cavity (Fig. 3D); large central posterior process located below basis of gonopods, sharply triangular in lateral view (Fig. 3C); in ventral view widely trapezoid, with slightly concave posterior margin. Lateral apodemes nearly horizontal (Fig. 3C), parallel-sided along their length, located at mid-height of segment IX, ending in sub-marginal line; tergal transverse apodemes absent; sternal transverse apodeme oriented in right angle to lateral apodeme, located along posterior margin of segment IX (Fig. 3C). Transverse plate absent. Tergum X, in lateral view, oriented posteroventrad (Fig. 3C), strongly tapering towards mid-length, with single, dorsolateral, stout seta at mid-length; distal half almost parallel-sided, apex slightly club-shaped, orienting posteroventrally (Fig. 3C); in dorsal view (Fig. 3D), deeply and narrowly divided into pair of parallel-sided and parallelrunning branches; each with 4 pairs equally long megasetae in apical group, and two pairs stout, posteradoriented spines (Fig. 3C). Superior appendages club-shaped (Fig. 3C), oriented posteroventrad. Primary branch of gonopods, in lateral view (Fig. 3C), with basal part oriented posterad before strongly bending posterodorsad, curving posterad after mid-length, apical part rounded in dorsal view; produced mesad into pointed plates above tergum $\mathrm{X}$ in dorsal view (Fig. 3D); slightly widening along their length; basal part of anterior margin smooth; dorsal and posterior margins undulating. Secondary branch of gonopods 
absent. Basomesal lobes long, slightly broadening before apex, each with pair of apical setae; straight in lateral view (Fig. 3C), diverging in ventral view (Fig. 3E). Basal plate, in lateral view (Fig. 3C), straight, strongly narrowing anteriorly towards mid-length, anterior half very slender, not produced beyond anteroventral margin of segment IX in lateral view (Fig. 3C); almost parallel-sided in ventral view (Fig. 3E), with rounded anterior apex. Phallic apparatus, lateral view, irregularly tube-shaped along its length (Fig. 3F), apex about as broad as base; nearly straight after mid-length; irregular in ventral view (Fig. 3G); widest after mid-length; endotheca weakly produced, posteroventral part not sclerotized, except long, single, weakly sclerotized triangular processes distally of phallic sclerite.
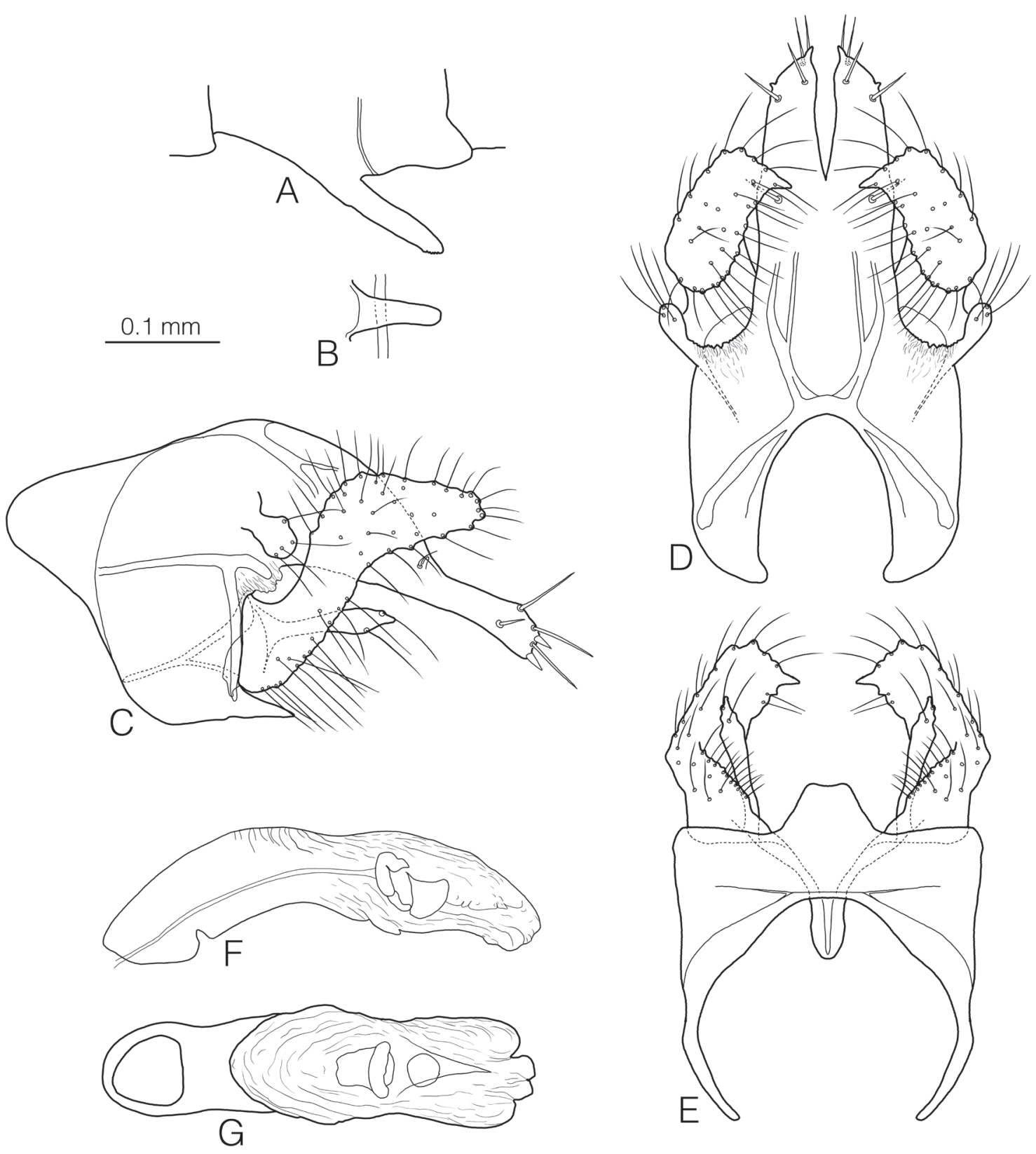

Fig. 3. Helicopsyche lamnata sp. nov., ô holotype. A. abdominal sternum VI, lateral view. B. abdominal sternal process VI, ventral view. C. genitalia, lateral view. D. genitalia, dorsal view. E. genitalia, ventral view. F. phallus, lateral view. G. phallus, ventral view. 


\section{Key to male Helicopsyche from Vietnam}

1. Maxillary palps each with two segments; gonopods without secondary branch...................................2

- Maxillary palps each with four segments; gonopods with secondary branch......................................6

2.(1) In genitalia, basomesal lobe absent (as in Fig. 1C)....H. boniata Malicky \& Chantaramongkol, 1992

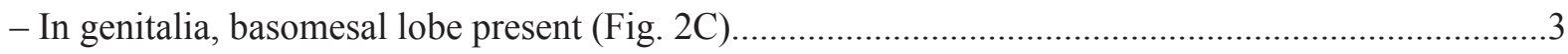

3.(2) In genitalia, basomesal lobe originated from ventral part of gonopod basis, resembling secondary branch of gonopods (as in Schefter \& Johanson 2001, figs 5, 9) ....................................................

- In genitalia, basomesal lobe originated from mid-height of gonopod basis (Fig. 2C)........................5

4.(3) In genitalia, segment IX about as long as high; tergum $X$ slender along its length in lateral view; in ventral view basomesal lobes fused mesally into common basal plate; in dorsal view, tergum $\mathrm{X}$ shallowly divided apically..

H. khemoiensis Schefter \& Johanson, 2001

- In genitalia, segment IX much higher than long; tergum $\mathrm{X}$ wide and posteriorly tapering in lateral view; in ventral view basomesal lobes separated; in dorsal view, tergum $\mathrm{X}$ deeply divided apically......

H. azwudschgal Malicky, 1995

5.(3) Sternite VI with sternal process about two-fifths as long as segment VI (Fig. 3A); posteroventral margin of segment IX produced posterad into large plate (Figs 3C, E); gonopods slightly sigmoid (Fig. 3C).

H. lamnata sp. nov.

- Sternite VI with sternal process about one-seventh as long as segment VI (Fig. 2A); posteroventral margin of segment IX not produced posterad (Fig. 2E); gonopods strongly sigmoid, bending about $90^{\circ}$ (Fig. 2C).

H. meander sp. nov.

6.(1) In genitalia, dorsal branch of gonopods almost parallel-sided in lateral view.

H. admata Malicky \& Chantaramongkol, 1992

- In genitalia, primary branch of gonopods widening distally in lateral view (Fig. 1C).....................7

7.(6) In genitalia, primary branch of gonopods produced anterad (Fig. 1C) H. melina sp. nov.

- In genitalia, primary branch of gonopods produced posterad.

8.(7) In genitalia, primary branch of gonopods shorter than secondary branch of gonopods; each lateral branch of tergum $\mathrm{X}$ divided apically.....

H. angusta Ulmer, 1951

- In genitalia, primary branch of gonopods longer than secondary branch of gonopods; each lateral branch of tergum $\mathrm{X}$ undivided apically..... H. dacklestenensis Schefter \& Johanson, 2001

\section{Acknowledgements}

This study was a collaboration between Institute of Ecology and Biodiversity Resources (IEBS), Hanoi, and the Swedish Museum of Natural History, Stockholm. We are particularly thankful to the director of IEBR, Prof. Dr. Le Xuan Canh, and vice director of IEBR Prof. Dr. Ta Huy Thinh for giving us the opportunity to perform this research. The present study was broadly supported by the basis project of the Department of Insect Systematics, IEBR, particularly by Mr. Thieu Du Tran who assisted us in the field.

\section{References}

Johanson K.A. 1997. Zoogeography and diversity of the snail case caddisflies (Trichoptera: Helicopsychidae). In: Holzenthal R.W. \& Flint O.S. Jr. (eds) Proceedings of the $8^{\text {th }}$ International Symposium on Trichoptera: 205-212. Ohio Biological Survey, Columbus, Ohio. 
Johanson K.A. 1998. Phylogenetic and biogeographic analysis of the family Helicopsychidae (Insecta: Trichoptera). Entomologica Scandinavica, Supplement 53: 1-172.

Johanson K.A. 1999. Seventeen new species of Helicopsyche from New Caledonia (Trichoptera: Helicopsychidae). Tijdschrift voor Entomologie 142: 37-64.

Johanson K.A. \& Malm T. 2007. Three new Helicopsyche from Laos (Trichoptera: Helicopsychidae). Zootaxa 1407: 13-22.

Malicky H. 1995a. Neue Köcherfliegen (Trichoptera, Insecta) aus Vietnam. Linzer Biologische Beiträge 27: 851-885.

Malicky H. 1995b. Zwei neue Helicopsyche (Helicopsychidae) aus Perak, Malaysia. Braueria 22: 4.

Malicky H. 2010. Atlas of southeast Asian Trichoptera. Faculty of Science Printing Unit, Chiang Mai University, Thailand.

Malicky H. \& Chantaramongkol P. 1992. Neue Köcherfliegen (Trichoptera) aus Thailand und angrenzenden Landern. Braueria 19: 13-23.

Malicky H., Chantaramongkol P., Bunlue P., Changthong N., Nawvong J., Nuntakwang A., Prommi T., Thamsenanupap P. \& Thapanya D. 2004. 27 neue Köcherfliegen aus Thailand (Insecta, Trichoptera). Linzer Biologische Beiträge 36: 287-304.

Melnitsky S. \& Malicky H. 2008. Trichoptera from Chang Island, southeastern Thailand, with the description of three new species. Braueria 35: 25-27.

Morse J.C. (ed.) 2011. Trichoptera World Checklist. http://entweb.clemson.edu/database/trichopt/index. $\underline{\mathrm{htm}}$ [Accessed $19 \mathrm{Jul} .2011$.

Oláh J. \& Johanson K.A. 2008. Generic review of Hydropsychinae, with description of Schmidopsyche, new genus, 3 new genus clusters, 8 new species groups, 4 new species clades, 12 new species clusters and 62 new species from the Oriental and Afrotropical regions (Trichoptera: Hydropsychidae). Zootaxa 1802: 1-248.

Schefter P.W. \& Johanson K.A. 2001. Three new species of Helicopsyche from Vietnam (Trichoptera: Helicopsychidae). Pan-Pacific Entomologist 77: 9-18.

Schmid F. 1993. Considérations sur les helicopsychides (Trichoptera, Integripalpia). Beaufortia 43: 65100.

Siebold C.T.E. von 1856. Wahre Parthenogenesis bei Schmetterlingen und Bienen. Wilhelm Engelmann, Leipzig.

Ulmer G. 1951. Köcherfliegen (Trichopteren) von den Sunda-Inseln. Teil I. Archiv für Hydrobiologie, Supplement 19: 1-528.

Manuscript received on: 27 July 2011

Manuscript accepted on: 16 November 2011

Published on: 2 February 2012

Topic editor: Malcom Scoble

In compliance with Article 8.6 of the ICZN, printed versions of all papers are deposited in the libraries of the institutes that are members of the EJT consortium: Muséum national d'Histoire naturelle, Paris, France; National Botanic Garden of Belgium, Meise, Belgium; Royal Museum for Central Africa, Tervuren, Belgium; Natural History Museum, London, United Kingdom; Royal Belgian Institute of Natural Sciences, Brussels, Belgium; Natural History Museum of Denmark, Copenhagen, Denmark. 